\title{
Gamma Glutamyl Transpeptidase: Measurement and Development in Guinea Pig Small Intestine
}

\author{
Mrahael I. Comen ${ }^{[34]}$, Lawrence M. Gartner, Olga O. Blumenfeld and Irwin M. Arias \\ Departments of Pediatrics, Biochemistry, and Medicine, Albert Einstein College of Medicine, Yeshiva University, \\ and the Division of Pediatrics, Montefiore Hospital and Medical Center, Bronx, New York, USA
}

\section{Extract}

A modification of a previous method for the assay of $\gamma$ gluta myl transpeptidase (GGTP) was developed. Substrate solubility difficulties alluded to by other investigators were avoided by employing heating and solubilization of the chromogenic substrate $\gamma$ glutamyl- $\beta$-naphthylamide in a medium of carbonate $0.05 \mathrm{M}$ and Tris buffer $0.1 \mathrm{M}$ at $\mathrm{pH}$ 9.5. The kinetics and conditions for such an assay are described. Whole intestinal homogenates of adult male guinea pigs were used as the source of the enzyme.

The developmental pattern of this enzyme was determined in fetuses at 55 and 63 days of gestation and at varying times from 1 to 90 days of age. A total of 69 animals was assayed. The general pattern was that of high specific activity during prenatal life, with a rapid decline during the neonatal period (3-24 days of age) and a slight increase after 55 days of age.

Other guinea pig organs were studied. Liver and kidney were found to contain enzyme activity greater than that of the intestine. Subcellular fractionation of intestinal mucosa using ultracentrifugation revealed a twenty-fold enrichment of activity in jejunal brush border membrane, compared with whole jejunal homogenates when expressed as specific enzyme activity per mg of protein. The stability characteristics of GGTP disclosed no loss of specific activity when stored at $-28^{\circ}$ for 50 days.

This simple enzyme assay, stability of the enzyme when frozen, subcellular distribution in the intestinal brush border membrane, and an unusual developmental pattern made this enzyme a useful adjunct to the study of intestinal protein metabolism.

\section{Speculation}

The unique ability of GGTP to hydrolyze $\gamma$ glutamic acid-peptide bonds and the location of the enzyme in the intestinal brush border suggest a role for this enzyme in the metabolism of an unusual group of physiologically important peptides such as glutathione, folic acid, and gluten-gliadin. The significance of these $\gamma$-bonded compounds may now be approached in order to investigate the role of this enzyme in gluten enteropathy and related disorders. 


\section{Introduction}

Gamma glutamyl transpeptidase (GGTP) is considered a single enzyme with a dual function $[12,16]$. It catalyzes both the hydrolysis of $\gamma$ glutamyl-containing peptide bonds and the transfer of $\gamma$ glutamyl groups from donor peptides to suitable acceptors, i.e. transpeptidation. GGTP activity has been found in many tissues $[3,11,13,23,27]$ of small laboratory animals [11], hog [26], cow [20], sea lion [2], and man $[3,11,13,23,27]$. Techniques originally developed for estimating GGTP activity involved quantitating the disappearance of glutathione and the appearance of the products of glutathione cleavage [4, 8, 28]. Since the specificity of GGTP is limited to $\gamma$ glutamyl bonds $[9,16,17]$, synthetic compounds other than glutathione, such as $\gamma$ glutamyl-p-nitroanilide [25] and $\gamma$ glutamyl- $\alpha$ - or $\beta$-naphthylamide $[1,10,23]$, may serve as suitable substrates. Compounds containing $\alpha$ glutamyl peptide or amide bonds cannot serve as substrates. In the present study, $\gamma$ glutamyl- $\beta$-naphthylamide was used as substrate because of availability and because the solubility difficulties noted by other investigators $[1,23]$ with other substrates were obviated.

Although the development of several enzymes associated with intraluminal or intramucosal protein digestion has been studied [22], these enzymes are all specific for $\alpha$ carboxyl-amide-linked peptides. The present report concerns the presence of a different type of intestinal peptidase, GGTP, which hydrolyzes only $\gamma$ carboxyl-amide bonds. This type of peptide bond is found only in a limited number of physiologically important peptides such as glutathione [18], folic acid [18], collagen [7], or gluten [2]. Study of the development of intestinal GGTP may provide information regarding the role of this enzyme in the metabolism of these important peptides and proteins containing $\gamma$ glutamyl bonds.

\section{Methods}

Purebred Hartley guinea pigs [31] were used in all assays. Controlled breeding techniques permitted accuracy in determining within 12 hours the age of the animals. The animals were fed Purina Guinea Pig Breeder Chow with an added daily ration of cabbage. Newborn guinea pigs were permitted to suckle. Food was withheld but water was permitted twelve hours prior to sacrifice. Only adult male animals were used in all kinetic studies. Both male and female animals were used for developmental studies during the first 24 days of age. Environmental conditions remained constant at approximately $50 \%$ relative humidity with ambient temperatures between $25-27^{\circ}$.
Immediately following decapitation, the small in testine was removed starting at the ileocecal valve and proceeding in a cephalad direction to the pylorus by sheering the mesentery at the serosal surface. The bowel was then placed in Tris buffer, $0.1 \mathrm{M}, \mathrm{pH} 9.5$, at $2^{\circ}$ and thoroughly washed free of blood and intraluminal detritus. Whole jejunum from the ligament of Trietz distally for approximately twelve centimeters was excised and weighed on a double beam balance. A whole jejunal homogenate, $1.25-20.0 \%$, was prepared by homogenation for 5 minutes in Tris buffer, $0.1 \mathrm{M}$, pH 9.5, at $2^{\circ}$ using a Vir-Tis ' $45^{\prime}$ ' homogenizer.

For preparation of brush border, animals were sacrificed as previously described. The bowel was cleaned as mentioned above except that $0.15 \mathrm{M} \mathrm{NaCl}$ at $2^{\circ}$ was used. A twelve-centimeter length of jejunum was opened on the antimesenteric border and spread on iced paraffin with the mucosal surface exposed. Mucosal scrapings were obtained by passing the edge of a glass slide over the mucosa. These scrapings were processed according to the method of ErchHolz and GRANE [6] for the preparation of brush border membranes. Morphological confirmation of membranes was obtained by phase microscopy.

The incubation mixture contained $0.5 \mathrm{ml}$ of enzyme source in Tris buffer $0.1 \mathrm{M}, \mathrm{pH} 9.5$, and $200 \mu \mathrm{g}$ of $\gamma$-glutamyl- $\beta$-naphthylamide [31] in $1 \mathrm{ml}$ solvent buffer. A control tube was prepared in an identical manner except that $1 \mathrm{ml}$ of $25 \%$ trichloracetic acid (TCA) was added prior to incubation. Both sample and control were subjected to incubation bath for 30 minutes at $37^{\circ}$. The substrate-buffer solution was prepared by adding $200 \mu \mathrm{g}$ of $\gamma$-glutamyl- $\beta$-naphthylamide to $0.5 \mathrm{ml}$ sodium carbonate $0.05 \mathrm{M}, \mathrm{pH} 9.5$, with constant stirring and heating to boiling for approximately 4 minutes. Then $0.5 \mathrm{ml}$ of Tris buffer $0.1 \mathrm{M}, \mathrm{pH} 9.5$, was added. Whole jejunal homogenates were prepared in a $5 \%$ concentration and $0.5 \mathrm{ml}$ of these homogenates was used. In the brush border preparations, $0.5 \mathrm{ml}$ of the membrane pellet resuspended in Tris buffer was used for assay of activity.

After completion of incubation, activity was stopped in the reaction tubes by the addition of $1 \mathrm{ml}$ of $25 \%$ TCA. Both reaction and control tubes were centrifuged at room temperature in an International centrifuge at $4000 \mathrm{rpm}$ for 15 minutes. One ml of clear supernatant was removed for coupling according to the method of Bratton and MARshall [5]. This involved the addition of $1 \mathrm{ml}$ of $0.1 \%$ sodium nitrite, after which the tube was shaken vigorously and allowed to stand for 3 minutes at room temperature. One $\mathrm{ml}$ of $1.0 \%$ ammonium sulfamate was then added, and the tube was shaken vigorously and allowed to stand for 2 minutes at room temperature. The reaction was completed by adding $2 \mathrm{ml}$ Bratton-Marshall reagent ( $\mathrm{n}$ - 
(1-naphthyl) ethylene diomine dihydrochloride) $0.5 \%$ and incubated at $37^{\circ}$ for 30 minutes in a Dubnoff incubation bath. The final incubation volume, following the addition of the Bratton-Marshall reagents, was $5 \mathrm{ml}$. $\beta$-naphthylamine [32] was used to establish a standard absorption spectrum. Readings were obtained from 460 to $660 \mathrm{~m} \mu$ using a Beckman DU spectrophotometer.

Whole jejunal homogenates of adult male guinea pigs were prepared and immediately assayed for GGTP as described above. Aliquots of homogenates were stored at 5 and $-28^{\circ}$ for 3 to 50 days and were then assayed for activity to ascertain the degree of enzyme stability. Tissue protein was determined according to the method of Lowry et al. [19].

\section{Results}

Maximum absorption of $\beta$-naphthylamine was noted at $570 \mathrm{~m} \mu$ (fig. 1). The absorbance was linear at $570 \mathrm{~m} \mu$ using a $1 \mathrm{~cm}$ light path with $\beta$-naphthylamine concentrations of $1-20 \mu \mathrm{g} / \mathrm{ml}$. Methodological studies of the enzyme were performed using $5 \%$ homogenates of whole guinea pig jejunum. Optimal conditions were: incubation for the enzyme-substrate reaction, $30 \mathrm{~min}-$ utes; temperature, $37^{\circ}$; substrate concentration, 200 $\mu \mathrm{g}$ of $\gamma$-glutamyl- $\beta$-naphthylamide $/ \mathrm{ml}$ incubation media; and $\mathrm{pH}, 9.5$ (fig.2). At a substrate concentration of $200 \mu \mathrm{g}$, the reaction was linear when 6.25 to $50.0 \mathrm{mg}$ wet weight of whole tissue served as a source of enzyme (fig. 3). Optimal incubation for the coupling reaction was 30 minutes. GGTP maintained optimal activity in whole tissue homogenates for 50 days at $-28^{\circ}$. Enzyme activity was greater in whole homogenates of liver and kidney than in comparable preparations of duodenum, jejunum, and ileum (fig.4). A 20 -fold enrichment in enzyme activity was noted in jejunal brush border membrane as opposed to whole jejunal homogenate when expressed as specific enzyme activity per mg of protein (fig. 5). Recovery of homogenate enzyme activity in jejunal brush border preparations ranged from 21 to $43 \%$.

A developmental curve of GGTP was determined by assaying guinea pig fetuses at 55 and 63 days of gestation and at $1,3,9,24,55$, and 90 days post partum (fig.6). A total of 69 animals was used. The overall pattern was that of high activity during prenatal life and at one day post-delivery, with a rapid decline during the neonatal period ( 3 through 24 days of age). There was a slight increase in activity after 55 days of age until adult values were achieved by 90 days of age. For purposes of statistical analysis, the eight ages studied were arbitrarily divided into three groups. The first group contained 9 fetuses from 2 prenatal age groups,

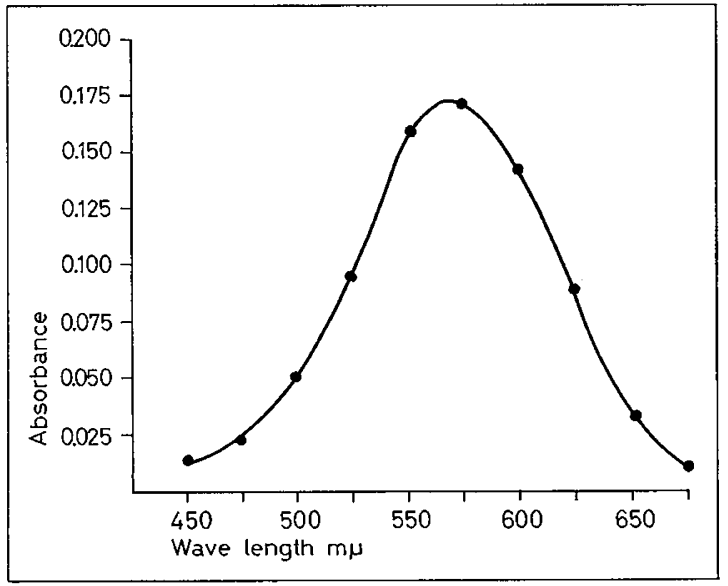

Fig. 1. Absorption spectrum of $\beta$ naphthylamine.

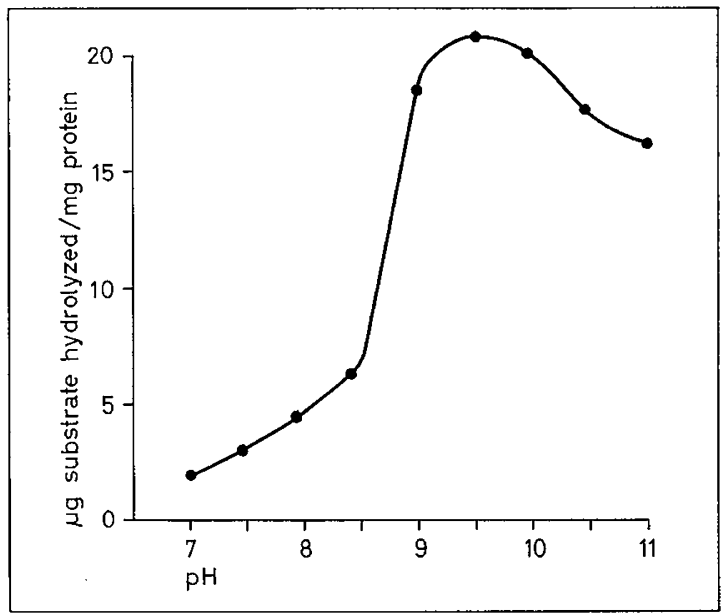

Fig.2. Effect of $\mathrm{pH}$ on GGTP activity.

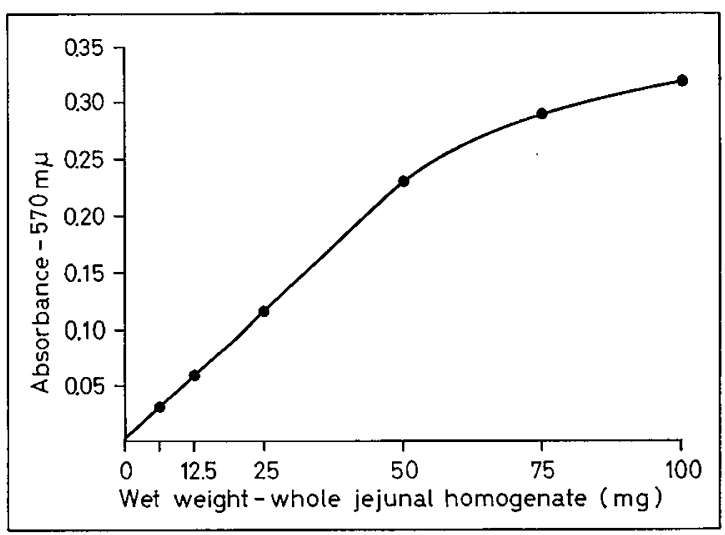

Fig. 3. Effect of varying enzyme concentration at constant substrate concentration. 


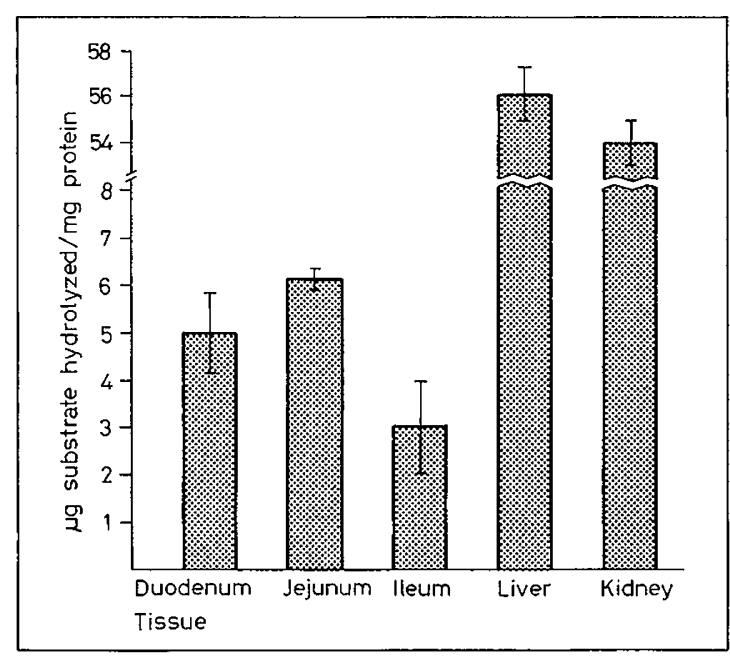

Fig.4. Tissue distribution of GGTP. This study was performed in 6 adult male guinea pigs. Results are expressed as the mean $\pm 1 \mathrm{SD}$.

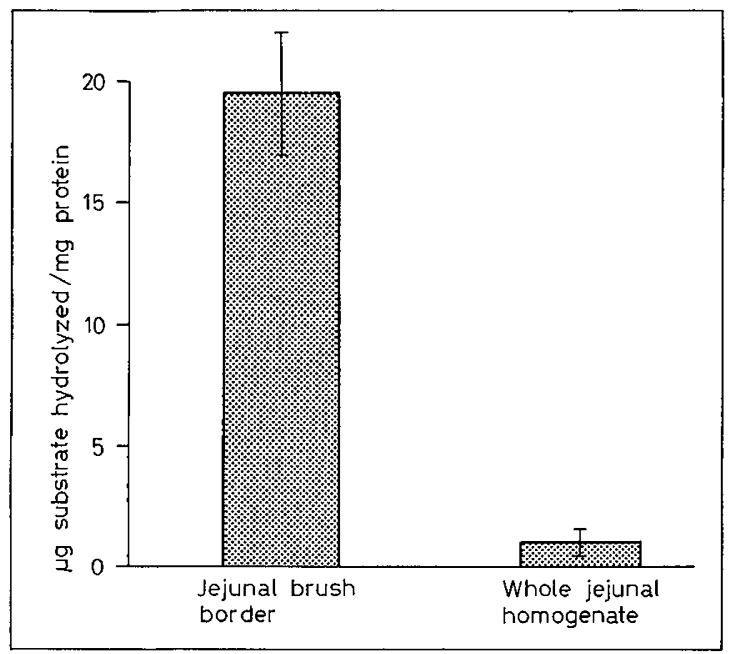

Fig. 5. Subcellular distribution of GGTP activity in jejunal mucosa. Four animals were used. Results are expressed as the mean $\pm 1 \mathrm{SD}$.

plus 5 newborns at 1 day post partum; the second group contained 29 animals from 3 to 24 days of age; and the last group contained 26 animals from 55 to 90 days of age. GGTP activity in jejunal homogenates in each of the three groups was significantly different $(p<0.01)$ using the Mann-Whitney U-test.

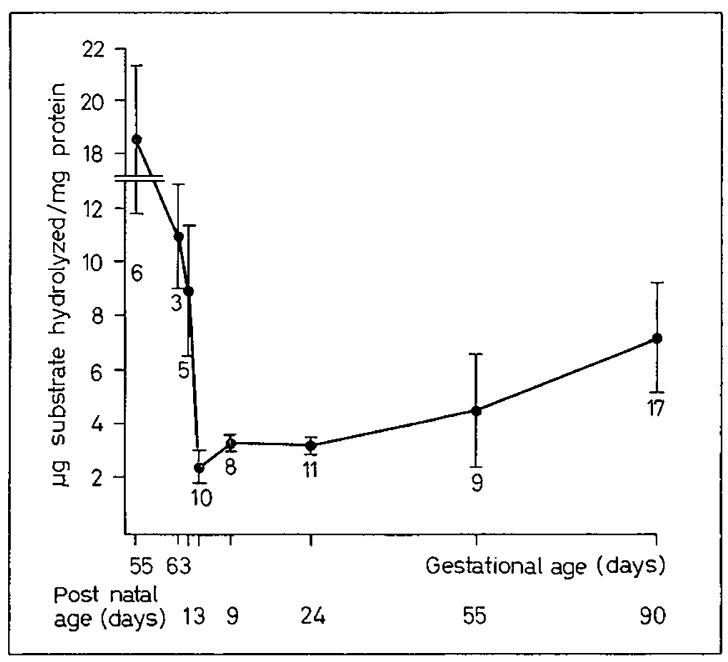

Fig.6. Changes in GGTP activity in whole jejunal homogenates from fetal, newborn, and adult guinea pigs. Results are expressed as the mean $\pm 1 \mathrm{SD}$. Numbers under each bar represent the number of individual animals assayed at respective age periods.

\section{Discussion}

Many of the early studies of GGTP indicated various solubility problems of the chromogenic substrates needed to assay for specific activity $[1,23]$. Determination of enzyme activity in this study was based on the ease with which $\gamma$-glutamyl- $\beta$-naphthylamide was solubilized with heat in a sodium carbonate-Tris buffer at an alkaline $\mathrm{pH}$. The application of this buffer system represents a modification of previous methodology. The colorimetric measurement of $\beta$-naphthylamine enzymatically cleaved from the substrate thus becomes a simple procedure. Inhibition appeared at concentrations in excess of $200 \mu \mathrm{g} / 100 \mathrm{ml}$, although $\gamma$-glutamyl- $\beta$-naphthylamide is soluble at concentrations ten-fold greater. The explanation for this phenomenon remains unclear. Although substrate inhibition may be present, it is more likely that interference occurs during the coupling reaction.

The biochemical and physiological significance of GGTP is uncertain. Some authors have suggested a role in the transport of amino acids across cell membranes [13], in the regulation of tissue levels of glutathione [16], and in the peptide-nitrogen storage [16, 30]. This enzyme is present in many organs and specifically in various portions of the gastrointestinal tract. In the small intestine it is localized to the mucosal brush border membrane. This localization suggests a possible role in synthesis, degradation, and/or trans- 
port of proteins containing $\gamma$ glutamyl bonds. Since most polypeptides are not linked in a $\gamma$ configuration, and those that are display resistance to the commonly found proteolytic intestinal enzymes, such an enzyme assay permits the study of a unique group of $\gamma$ glutamylcontaining peptides and proteins. The physiological significance of these $\gamma$-bonded compounds may now be approached in order to understand better their activity in sprue, celiac disease, and related disorders.

The developmental pattern of an intestinal peptidase in the guinea pig is described in this study. The elevated levels of GGTP in the intestine in the immediate perinatal period suggest a possible action in the metabolism of amniotic fluid protein and/or intestinal meconium. The seemingly paradoxically low levels of GGTP soon after delivery lend indirect evidence to support the concept that whole protein traverses intestinal mucosa during the neonatal period $[14,15,21]$. It would appear from the present data that the neonatal guinea pig may have considerable difficulty in digesting and absorbing $\gamma$ glutamyl bonded peptides and proteins.

The developmental relation of GGTP to other brush border proteases is unknown. An opportunity is now available to study the development of the brush border peptidase population and to determine whether this development occurs at a single rate or whether brush border enzymes have asynchronous turnover.

\section{Summary}

A modification of the previous methodology for determining $\gamma$ glutamyl transpeptidase activity in guinea pig tissue homogenates is described. The developmental pattern of this intestinal peptidase in the neonatal guinea pig and a discussion of the possible metabolic role of this enzyme is presented.

\section{References and Notes}

1. Albert, Z.; Orlowski, M. and Szewczuk, A.: Histochemical demonstration of gamma-glutamyl transpeptidase. Nature, Lond. 191: 767 (1961).

2. Arias, I.M.; Gartner, L.M. and Cohen, M.I.: Unpublished data.

3. Aronsen, K.F.; Hanson, A. and Nosslin, B. : The value of $\gamma$-glutamyl transpeptidase in differentiating viral hepatitis from obstructive jaundice. A statistical comparison with alkaline phosphatase. Acta chir. scand. 130: 92 (1965).

4. Ball, E.G.; Revel, J.P. and Cooper, O.: The quantitative measurement of $\gamma$-glutamyl transpeptidase activity. J. biol. Chem. 221: 895 (1956).
5. Bratton, A.C. and Marshall, E.K.: A new coupling component for sulfanilamide determination. J. biol. Chem. 128: 537 (1939).

6. Erchrolz, A. and Crane, R.K.: Studies on the organization of the brush border in intestinal epithelial cells. J. Cell Biol. 26: 687 (1965).

7. Franzblau, G.; Gallop, P.M. and Seifter, S.: The presence in collagen of $\gamma$-glutamyl peptide linkages. Biopolymers 1: 79 (1963).

8. Fodor, P.J.; Muller, A. and Waelsch, H. : Quantitative aspects of enzymatic cleavage of glutathione. J.biol. Chem. 202: 551 (1953).

9. Fodor, P.J.; Mrller, A.; Neidle, A. and Wael WaElsch, H.: Enzymatic synthesis of glutathione by a transfer reaction. J. biol. Chem. 203: 991(1953).

10. Glenner, G.G. and Folk, J.E.: Histochemical localization of an enzyme having the characteristics of $\gamma$-glutamyl transpeptidase. J. Histochem. Cytochem. 9: 624 (1961).

11. Goldberg, J.A.; Friedman, O.M.; Pineda, E. P.; Smirh, E.E.; Chatrerji, R.; Stein, E.H. and RutenburG, A.M.: The colormetric determination of $\gamma$-glutamyl transpeptidase with a synthetic substrate. Arch.Biochem. 91: 61 (1960).

12. Goore, M.Y. and Thompson, J.F.: $\gamma$-Glutamyl transpeptidase from kidney bean fruit. I. Purification and mechanism of action. Biochem. biophys. Acta 132: 15 (1967).

13. Greenberg, E.; Wollaeger, E.E.; Fleisher, G.A. and Engstrom, G.W.: Demonstration of $\gamma$-glutamyl transpeptidase activity in human jejunal mucosa. Clin. chim. Acta 16: 79 (1967).

14. HALlIDAY, R.: The absorption of antibodies from immune sera by the gut of the young rat. Proc. roy. Soc. B 143: 408 (1955).

15. Halliday, R.: Prenatal and postnatal transmission of passive immunity to young rats. Proc. roy. Soc. B. 144: $427(1955 / 56)$.

16. HAnes, C.S.; Hird, F.J.R. and Isherwood, F.A.: Synthesis of peptides in enzymic reactions involving glutathione. Nature Lond. 166: 288 (1950).

17. Hanes, C.S.; Hird, F.J.R. and Isherwood, F.A.: Enzymic transpeptidation reactions involving $\gamma$ glutamyl peptides and $\gamma$-amino-acyl peptides. Biochem.J. 51: 25 (1952).

18. Haurowitz, F. and Bursa, F.: The linkage of glutamic acid in protein molecules. Biochem.J. 44: 509 (1949).

19. Lowry, O.H.; Rosebrough, N.J.; FArr, A.L. and Randall, R.J.: Protein measurements with the folin phenol reagent. J.biol. Chem. 193: 265 (1951).

20. Morton, R.K.: Separation and purification of enzymes associated with insoluble particles. Nature Lond. 166: 1092 (1950). 
21. Mosinger, B.; Placer, Z. and Koldovskxy, O.: Passage of insulin through the wall of the gastrointestinal tract of the infant rat. Nature, Lond. 184: 1245 (1959).

22. Noack, R.; Koldovskx, O.; Friedrich, M.; Heringová, A.; Jirsová, V. and Schenk, G.: Proteolytic and peptidase activities of the jejunum and ileum of the rat during postnatal development. Biochem.J. 100: 775 (1966).

23. Orlowski, M. and Szewczuk, A.: Colorimetric determination of $\gamma$-glutamyl transpeptidase activity in human serum and tissues with synthetic substrates. Acta biochim. pol. 8: 189 (1961).

24. Orlowski, M. and Szewczuk, A.: A note on the occurrence of $\gamma$-glutamyl transpeptidase in human serum. Clin. chim. Acta 6: 430 (1961).

25. Orlowski, M. and Meister, A.: $\gamma$-Glutamyl-pnitroanilide: A new convenient substrate for determination and study of L- and D- $\gamma$-glutamyl transpeptidase activities. Biochem. biophys. Acta 73: 679 (1963).

26. Orlowskr, M. and Meister, A.: Isolation of $\gamma$ glutamyl transpeptidase from hog kidney. J. biol. Chem. 240: 338 (1965).
27. Orlowskr, M. and Szczerlik, A.: Heterogenity of serum $\gamma$-glutamyl transpeptidase in hepatobiliary disease. Clin. chim. Acta 15: 387 (1967).

28. Patterson, J.W. and Lazarow, A.: in Methods of biochemical analysis (ed. Gurck, D.), vol.2, p. 273 (New York 1955).

29. Rutenburg, A.M.; Goldberg, J.A.; Friedman, O.M.; Smith, E.E. and Pineda, E.P.: A new method for the colorimetric assay of $\gamma$-glutamyl transpeptidase. J. Histochem. Cytochem. 8: 343 (1960).

30. Szewczuk, A. and Orlowskr, M.: The use of $\alpha$ (N- $\gamma$-dL-glutamyl)-aminonitriles for the colorimetric determination of a specific peptidase in blood serum. Clin. chim. Acta 5: 680 (1960).

31. Sigma Chemical Co., St. Louis, Mo.

32. Fisher Scientific Co., Springfield, N.J.

33. Supported in part by grants from the National Institute of Arthritis and Metabolic Disease (AM02019 and TI AM-05384).

34. Requests for reprints should be addressed to: Michael I.Cohen, M.D., Pediatric Division, Montefiore Hospital and Medical Center, 111 East 210th St., Bronx, N.Y. 10467 (USA). 